\title{
INTEGRATING PROBLEM-BASED LEARNING AND TEAM-BASED LEARNING (PITBL) IN NURSING STUDENTS: A PILOT STUDY
}

\author{
Yossi Indra Kusuma*, Gandes Retno Rahayu**, Savitri Shitarukmi** \\ * Faculty of Medicine and Health Sciences, Universitas Islam Negeri Maulana Malik Ibrahim, Malang - INDONESIA \\ ** Faculty of Medicine, Universitas Gadjah Mada, Yogyakarta - INDONESIA
}

\begin{abstract}
Background: Change seems to be a constant in education. The shifting paradigm from teacher-centered to studentcentered impact on demands of medical and health professions education institution to undertake curricullum reform. The development of PBL requires the provision of resources needed for its implementation. The emergence of newly developed method, TBL, garnered interest because of its potential to promote active learning without requiring large numbers of resources. The integration of these two methods can complement each deficiencies with their advantages, so it can optimize student learning. This study is aimed to determine the impact of the integration of PBL and TBL (PiTBL) on student engagement and to evaluate the perceptions of students in terms of accountability, preferences and their satisfaction with this method.

Method: This study was a pre-experimental with one group pre and post test design. Subjects consisted of 103 nursing students who enrolled Fluid, Electrolyte an Elimination course. The collection of data before and after the intervention were held to determine the difference in student engagement, using "Classroom Engagement Survey" instrument from Baylor University. Students perceptions in terms of accountability, preference and satisfaction were measured with PiTBL-Student Assessment Instrument (PiTBL-SAI).

Results: PiTBL had a positive impact on student engagement, but its results were lower then PBL. The difference was not significant for participation sub-scale, and significant in several weeks of course for enjoyment sub-scale and total value of student engagement. Students perceptions in terms of accountability, preference and their satisfaction with PiTBL all showed positive results.

Conclusions: PiTBL had a positive impact on student engagement, although lower than PBL. Students perceptions in terms of their accountability, preference and satisfatction with this method is also positive. We concluded that this method can be used as an alternative in implementing an effective and eficient active learning method.
\end{abstract}

Keywords: Team-Based Learning, Problem-Based Learning, PBL and TBL integration, combining PBL and TBL, student engagement.

\begin{abstract}
ABSTRAK
Latar belakang: Pergeseran paradigma pembelajaran dari teacher-centered menjadi student-centered berdampak tuntutan dari institusi pendidikan kedokteran dan profesi kesehatan untuk melakukan reformasi kurikulum. Perkembangan metode pembelajaran PBL menuntut penyediaan sumber daya yang dibutuhkan dalam implementasinya. Munculnya TBL memberikan alternatif metode pembelajaran aktif yang tidak membutuhkan banyak sumber daya. Integrasi kedua metode ini dapat melengkapi kekurangan dengan kelebihan dari masing-masing, sehingga dapat mengoptimalkan proses pembelajaran pada mahasiswa. Penelitian ini bertujuan untuk mengetahui dampak dari integrasi metode pembelajaran PBL dan TBL (PiTBL) pada student engagement dan melakukan survei terhadap persepsi mahasiswa dalam hal akuntabilitas, preferensi dan kepuasan mereka terhadap PiTBL.
\end{abstract}

Contact: yossi.indrakusuma@gmail.com 
Metode: Penelitian ini menggunakan desain pre eksperimental dengan one group pre and post test design. Subjek penelitian terdiri dari 103 mahasiswa keperawatan yang mengikuti Blok Fluid, Elektrolyte and Elimination. Pengumpulan data sebelum dan sesudah intervensi dilakukan untuk melihat perbedaan student engagement, menggunakan instrumen "Classroom Engagement Survey" dari Baylor University. Persepsi dalam hal akuntabilitas, preferensi dan kepuasan mahasiswa terhadap PiTBL diukur dengan instrumen PiTBL-Student Assessment Instrument (PITBL-SAI).

Hasil: Metode PiTBL berdampak positif terhadap student engagement, namun tidak lebih tinggi dibandingkan PBL. Perbedaan tidak signifikan untuk sub-skala partisipasi, dan signifikan di beberapa pengukuran sub-skala enjoyment serta nilai total student engagement. Persepsi mahasiswa dalam hal akuntabilitas, preferensi dan kepuasan mereka terhadap metode pembelajaran PiTBL semuanya menunjukkan hasil yang positif.

Kesimpulan: Meskipun tidak mengalami peningkatan dibandingkan PBL, metode PiTBL berdampak positif terhadap student engagement. Persepsi mahasiswa dalam hal akuntabilitas, preferensi dan kepuasan mereka terhadap metode ini juga positif. PiTBL dapat digunakan sebagai alternatif dalam mengimplementasikan metode pembelajaran aktif yang efektif dan efisien.

Kata kunci: Team-Based Learning, Problem-Based Learning, integrasi PBL dan TBL, student engagement.

\section{PENDAHULUAN}

Perubahan adalah menjadi karakteristik tetap dalam sebuah masyarakat dan sistem pelayanan kesehatan. Sehingga proses pembaruan kurikulum yang berkelanjutan menjadi hal yang familiar dilakukan di pendidikan kedokteran dan profesi kesehatan. Hal ini bertujuan untuk meningkatkan kualitas dari proses dan hasil pembelajaran yang dilakukan. ${ }^{1,2}$ Reformasi besar dalam perubahan ini adalah pergeseran paradigma pembelajaran dari teacher-centered menjadi student-centered, yang dimulai dengan berkembangnya metode pembelajran Problem-Based Learning (PBL) dan diikuti oleh metode-metode pembelajaran aktif lainnya, seperti Team-Based Learning (TBL).,4

Berkembang pesatnya kedua metode pembelajaran ini menimbulkan pertanyaan: manakah yang lebih baik? Beberapa literatur menyebutkan bahwa selain memiliki beberapa perbedaan, kedua metode ini memiliki kesamaan dalam hal: sama-sama berdasarkan pada teori pembelajaran konstruksivisme, yaitu mahasiswa didorong untuk mengaplikasikan pengetahuan baru yang didapat untuk membahas sebuah kasus dalam kelompok yang kemudian mengintegrasikan pengetahuan- pengetahuan baru tersebut untuk disampaikan kepada anggota kelompoknya; hasil belajar berupa penguasaan yang progresif dari pengetahuanpengetahuan yang fundamental dan aplikasi dari pengetahuan tersebut untuk problem solving; mampu mengembangkan kemampuan berkomunikasi efektif; mempu meningkatkan student engagement; dan mampu meningkatkan performa akademik mahasiswa. ${ }^{2,5,6}$

Literatur juga menyebutkan perbedaan kedua metode ini berupa keunggulan dan kelemahan dari masing-masing. Jika diintegrasikan maka keunggulan dari masing-masing metode akan dapat menutupi kelemahan-kelemahan yang dimiliki, sehingga dapat meningkatkan kualitas dari proses dan hasil pembelajarannya. ${ }^{2}$ PBL dianggap unggul dari TBL dalam hal adanya aktivasi dari priorknowledge yang didapatkan dari diskusi kelompok kecil sebelum self-study yang dianggap memiliki efek positif pada kemampuan kognitif mahasiswa. ${ }^{2}$ Sementara TBL dianggap memiliki keunggulan dalam hal kemampuannya dalam menciptakan efektifitas dalam pembelajaran kelompok kecil yang independen dalam kelas yang besar, hingga pada rasio mahasiswa berbanding dosen $>200: 1$, 
tanpa menghilangkan efek positif dari peran dosen sebagai fasilitator pembelajaran dalam kelompok kecil. ${ }^{1,7}$

Sekolah Tinggi Ilmu Kesehatan Achmad Yani Yogyakarta (STIKES A. Yani) merupakan salah satu institusi pendidikan kesehatan yang responsif dalam menyikapi perkembangan di bidang pendidikan. Hal ini dibuktikan dengan penerapan Kurikulum Berbasis Kompetensi $(\mathrm{KBK})$ dengan metode pembelajaran PBL di instistusi ini sejak tahun ajaran 2013-2014. Sebagai institusi pendidikan kesehatan swasta yang baru berdiri sejak tahun 2005, pada awal penerapan PBL institusi ini mengalami beberapa kendala, seperti permasalahan klasik yang dialami institusiinstitusi lain, yaitu kurangnya SDM yaitu dosen yang menjadi fasilitator dalam tutorial PBL. Hal ini menyebabkan Program Studi S1 Keperawatan di STIKES Achmad Yani berkeinginan untuk mencoba inovasi pembelajaran berupa metode pembelajaran yang efektif dan efisien, sesuai dengan sumber daya yang mereka miliki.

Oleh karena itu, melihat kebutuhan akan adanya inovasi terhadap metode pembalajaran peneliti ingin melakukan uji coba (pilot project) dari integrasi metode pembelajaran PBL dan TBL di STIKES Achmad Yani. Dengan merujuk kepada model integrasi metode pembelajaran PBL dan TBL dari Dolmans et $\mathrm{al}^{2}{ }^{2}$ yaitu dengan memasukkan karakteristik penting dari PBL ke dalam TBL, peneliti akan menilai keberhasilan dari metode ini dengan menilai dampaknya terhadap student engagement, akuntabilitas, preferensi serta kepuasan mahasiswa di Prodi S1 Keperawatan STIKES Achmad Yani. Peneliti menggunakan istilah PiTBL (Problem-based In Team-Based Learning) pada integrasi metode pembelajaran PBL dan TBL tersebut.

\section{METODE}

Penelitian ini menggunakan desain penelitian kuantitatif pre-eksperimental, yaitu One-Group Pretest-Posttest Design, untuk melihat dampak dari intervensi metode pembelajaran PiTBL terhadap student engagement. Pengumpulan data sebelum intervensi dilakukan untuk menilai student engagement pada metode pembelajaran PBL, dan pengumpulan data setelah intervensi dilakukan di tiap akhir minggu (lima kali dalam lima Minggu pembelajaran Blok) untuk menilai student engagement pada PiTBL. Selain itu peneliti juga akan melakukan survei di akhir intervensi untuk menilai persepsi mahasiswa dalam hal akuntabilitas, preferensi dan kepuasan mereka terhadap pengalaman belajar dengan metode pembelajaran ini. Kelompok perlakuan adalah mahasiswa Prodi S1 Keperawatan STIKES Achmad Yani angkatan 2014 sejumlah 2 kelas yang mengikuti Blok Fluid, Elektrolyte and Elimination. Seluruh partisipan, sejumlah 103 mahasiswa, mengikuti metode pembelajaran PiTBL, dan dibagi menjadi dua puluh tim. Masing-masing Tim terdiri dari 5-6 partisipan, dan seluruh tim melaksanakan pembelajaran PiTBL di dalam satu kelas besar. Terdapat tiga fase dalam implementasi PiTBL penelitian ini, yaitu:

\section{Fase I: Persiapan}

Yang dilakukan pada fase persiapan adalah:

1. perijinan, sosialisasi dan koordinasi dengan pejabat struktural STIKES Achmad Yani

2. penentuan Blok Pembelajaran, sosialisasi, koordinasi dan mini workshop kepada Tim Blok

3. Persiapan Modul Pembelajaran (pengelompokan konten pembelajaran, penentian aktivitas pembelajaran mingguan, pembuatan skenario kasus PiTBL pertemuan I (skenario PBL) dan II (skenario TBL), pembuatan soal Tes Kesiapan, penentuan SDM pembelajaran, pembagian kelompok, penentuan komposisi nilai/grading).

4. Sosialisasi PiTBL kepada dosen dan mahasiswa

5. Persiapan pengumpulandata(penerjemahan instrumen, modifikasi instrumen dan uji keterbacaan).

\section{Fase II: Implementasi PiTBL dan pengumpulan data}

Peneliti bersama dengan Tim Blok melakukan implementasi PiTBL pada Blok Fluid, Elektrolyte and Elimination selama 5 minggu. PiTBL dilakukan di tiap minggu dengan dua kali pertemuan diskusi dalam kelas besar. Pada 
pertemuan pertama PiTBL, kegiatan diskusi tutorial dilakukan seperti pertemuan pertama PBL klasik, dengan menggunakan seven jumps (Step 1-5). Hanya saja kegiatan diskusi tutorial ini dilakukan dalam kelompok-kelompok kecil pada satu kelas besar. Kegiatan dilanjutkan dengan self-study, identik dengan Step 6 pada diskusi tutorial PBL atau pre-class preparation pada tahap awal TBL. Namun self-study tidak hanya LO yang didapatkan pada diskusi tutorial saja, melainkan juga dari kuliah, praktikum dan latihan keterampilan medik di Skills Lab. LO untuk bahan belajar di luar LO yang dirumuskan pada saat diskusi tutorial dapat diketahui oleh mahasiswa pada Buku Modul yang telah dibuat oleh Tim Blok. Tahap berkutnya dilanjutkan dengan pertemuan kedua yaitu pelaksanaan TBL tahap 2 dan 3 seperti pada classical TBL: Readiness Assurance Process (RAP) dan Team Application (tAPP).

Pertemuan I PiTBL (PBL in large class). Diskusi tutorial dalam pertemuan ini difasilitasi oleh 4 orang dosen yang bertindak sebagai floating tutor. Setiap dosen memfasilitasi diskusi untuk 5 Tim. Tahapan dalam pertemuan I ini meliputi:

1. Diskusi intra-tim merumuskan LO $(2 \times 50$ menit)

2. Break

3. Appeal dan diskusi inter-tim menyepakati konsensus LO (2x50 menit)

Pertemuan II PiTBL (in-class TBL) -

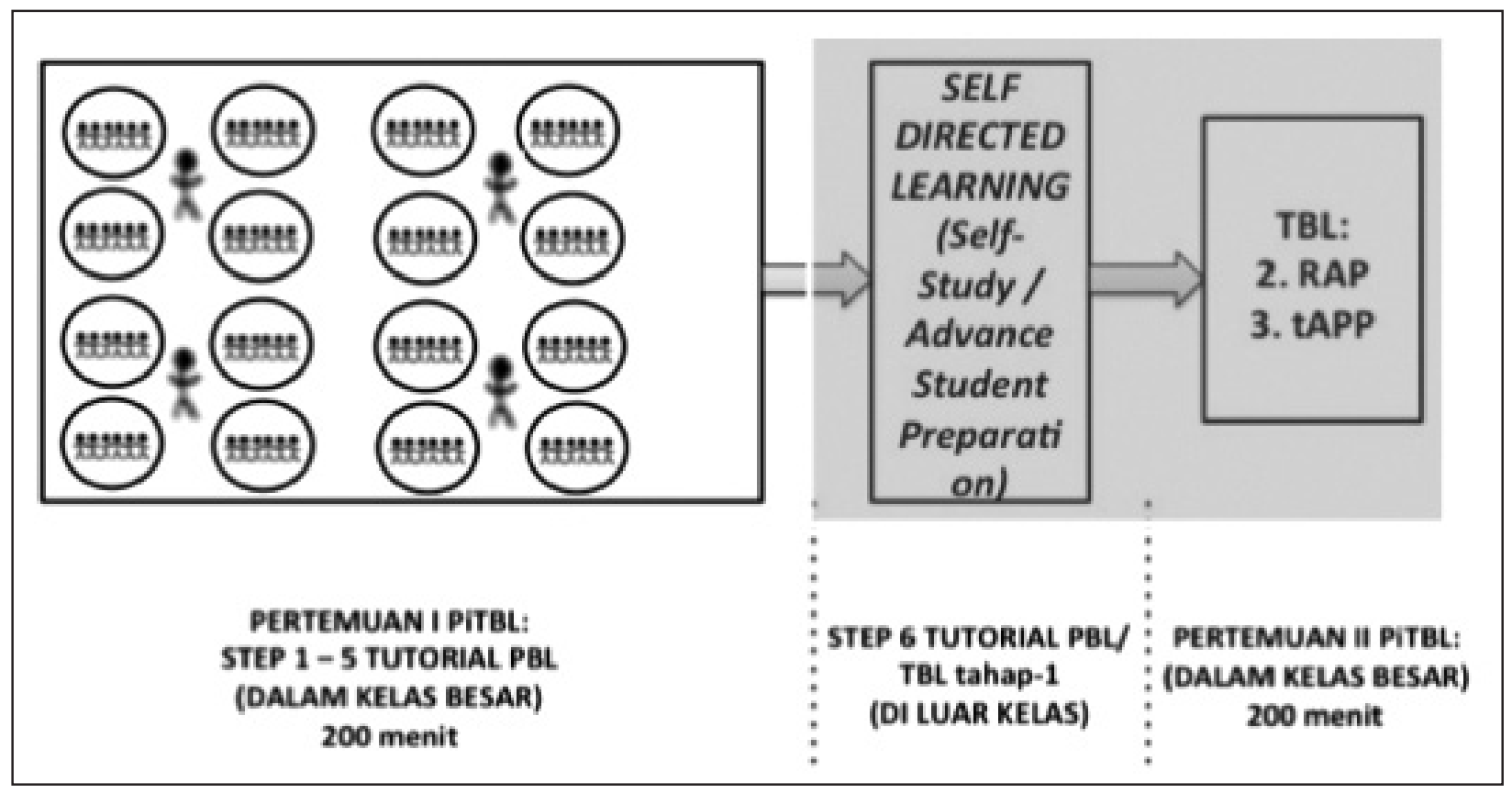

Gambar 1. Pertemuan-I PiTBL

Pertemuan ini dipandu oleh seorang instruktur yaitu content expert yang sesuai dengan tema yang didiskusikan. Pelaksanaannya mengacu kepada panduan TBL dalam AMEE Guide no. $65^{8}$.

\section{Fase III: Analisis Data}

Data hasil penelitian yang diperoleh adalah data kuantitatif berupa data tentang hasil pretest dan post-test dari Student Engagement, serta data kuantitatif dan kualitatif dari hasil survei PiTBL-SAI tentang persepsi mahasiswa dalam hal akuntabilitas, preferensi dan kepuasan mereka terhadap pengalaman belajar PiTBL. 


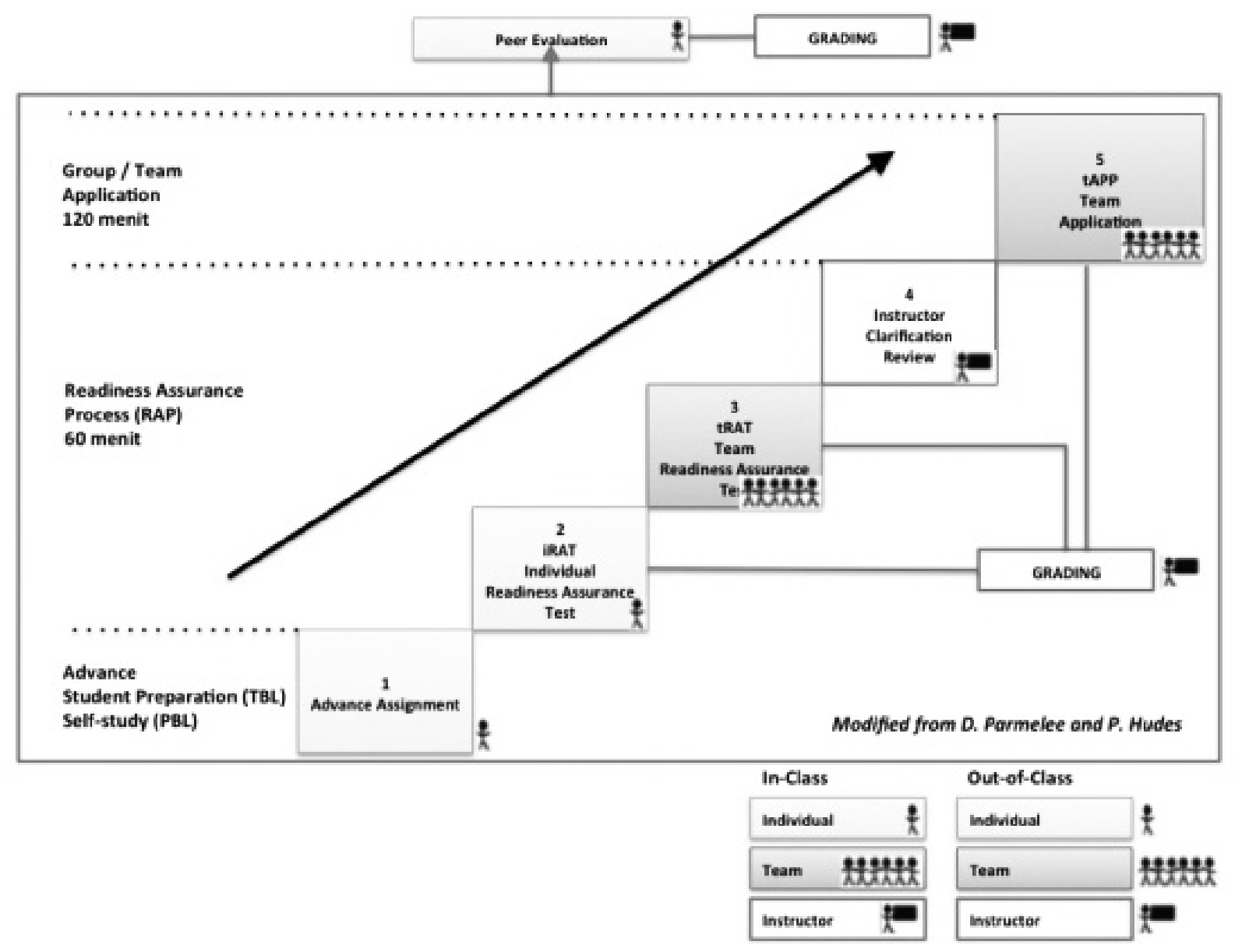

Gambar 2. Pertemuan-II PiTBL

(Diadaptasi dari "Team-based learning: A practical guide: AMEE Guide No. 65", oleh D.Parmelee, LK. Michaelsen, S.Cook dan PD. Hudes, 2012)

Instrumen penilaian terhadap student engagement menggunakan "Classroom Engagement Survey" dari Fund for the Improvement of Post-secondary Education (FIPSE), Baylor University. ${ }^{9}$ Instrumen ini terdiri dari 8 item pertanyaan yang bertujuan untuk mengukur student engagement pada nilai total, sub-skala partisipasi dan sub-skala enjoyment selama proses pembelajaran dalam kelas. ${ }^{10} \mathrm{Uji}$ coba dari instrumen yang dilakukan oleh FIPSE (2003) menunjukkan validitas yang tinggi. Instrumen ini juga telah digunakan oleh 3 penelitian tentang TBL yaitu oleh Clark et al (2008), FIPSE (2003), dan Levine et al (2004). Dan ketiga penelitian ini mengindikasikan bahwa instrumen ini adalah reliabel dan valid untuk mengukur student engagement. Pada penelitian Mennenga (2010) penilaian terhadap reliabilitas pada instrumen ini memberian nilai Alpha Cronbach sebesar 0.881 untuk nilai total, 0.807 untuk subskala partisipasi dan 0.873 untuk subskala enjoyment. ${ }^{10}$

Untuk mengukur persepsi mahasiswa terhadap pengalaman belajar menggunakan PiTBL, peneliti memodifikasi instrumen yang dikembangkan pada penelitian sebelumnya. Instrumen ini menilai akuntabilitas, preferensi dan kepuasan mahasiswa terhadap TBL, yaitu "Team-Based Learning Student Assessment Instrument (TBL-SAI)". ${ }^{10}$ Modifikasi dilakukan kepada komponen penilaian terhadap preferensi mahasiswa, yang sebelumnya menilai preferensi mahasiswa terhadap metode pembelajaran tradisional dengan TBL. Pada penelitian ini peneliti ingin menilai preferensi 
mahasiswa terhadap metode PiTBL atau PBL. Instrumen ini diberi istilah oleh peneliti sebagai PiTBL-SAI.

Analisis data kuantitatif hasil student engagement menggunakan acuan nilai netral baik dari nilai total maupun masing-masing subskala. Untuk melihat signifikansi perbedaan student engagement antara pre-test dan post-test serta antar posttest, dilakukan Uji Repeated Anova dengan nilai kepercayaan $95 \%(p<0.05)$. Sebelumnya dilakukan uji normalitas dan uji homogenitas sebagai prasyarat dilakukannya uji Repeated Anova. Dalam penelitian ini student engagement yang akan dibandingkan ada 6 kali pengukuran, yaitu pre-test (PBL), posttest Minggu-I sampai dengan Minggu-V (PiTBL). Analisis data kuantitatif hasil survei PiTBL-SAI teknis penilaiannya dilakukan dengan mengunakan panduan penilaian PiTBL-SAI. Untuk data kualitatifnya peneliti melakukan analisis konten, dengan dibantu oleh 2 koder yaitu mahasiswa S2 Ilmu Pendidikan Kedokteran. Hasil koding akan dikategorikan berdasarkan tema-tema tertentu, dan hasilnya digunakan untuk menunjang pembahasan dari hasil data kuantitatif.

Penelitian ini diajukan ke Komite Bioetika Fakultas Kedokteran Universitas Gadjah Mada (Ref: KE/ FK/632/EC/2016). Sebelum proses pengambilan data dimulai, seluruh target sampel penelitian diberikan lembar persetujuan dan informasi tentang jalannya penelitian untuk meminta kesediaan dan persetujuan mengikuti penelitian ini.

\section{HASIL DAN PEMBAHASAN}

\section{Implementasi PiTBL}

Metode PiTBL merupakan integrasi dari dua metode pembelajaran, yaitu PBL dan TBL. Terdapat banyak variasi dalam pelaksanaan kedua metode pembelajaran ini, sehingga peneliti menganggap hal ini penting untuk diperhatikan supaya pelaksanaan keduanya sesuai dengan kaidah yang disepakati. Kriteria kunci pelaksanaan PBL yang perlu diperhatikan adalah penggunaan skenario kasus, kelompok kecil untuk diskusi tutorial dan adanya aktivitas self-directed learning. ${ }^{11}$ Demikian juga untuk TBL, ada syarat-syarat yang harus dipenuhi dalam pelaksanaannya. Dalam penelitian ini peneliti menggunakan beberapa referensi sebagai acuan supaya tidak terjadi penyimpangan dari implementasi kedua metode tersebut.

Pada pertemuan-I PiTBL yang identik dengan pertemuan-I diskusi tutorial PBL dalam perumusan LO, peneliti memodifikasi dengan penggunaan kelas besar untuk diskusi seluruh kelompok, jumlah kelompok yang lebih kecil (5-7 orang), dan penggunaan satu tutor sebagai fasilitator diskusi untuk beberapa kelompok (floating tutor). Dalam hal ini peneliti mengacu kepada beberapa referensi implementasi PBL in large class seperti penelitian dari Pastirik, ${ }^{12}$ Kingsbury \& Lymn ${ }^{11}$ dan Nicholl \& Lou. ${ }^{13}$

TBL juga memiliki banyak variasi dalam pelaksanaannya. Sehingga pakar-pakar pendidikan dalam metode pembelajaran ini membuat guidelines bagi institusi yang ingin mengimplementasikan, supaya tujuan dari TBL dapat tercapai dengan maksimal ${ }^{13}$. Panduan tersebut menyatakan terdapat tujuh elemen utama yang harus dilakukan dalam implementasi TBL, yaitu: 1) pembentukan Tim, 2) adanya tes kesiapan (RAP), 3) immediate feedback, 4) aktivitas pembelajaran yang berjenjang dalam kelas, 5) kaidah 4's, 6) incentive structure, dan 7) adanya peer review. ${ }^{14}$ Dan dalam implementasi pertemuan-II PiTBL, yang identik dengan tahap inclass TBL, peneliti memenuhi kaidah yang tertulis dalam guidelines tersebut.

\section{Student Engagement}

Sebanyak seratus tiga mahasiswa keperawatan yang berasal dari dua kelas dibagi menjadi dua puluh Tim, masing-masing Tim terdiri dari lima enam mahasiswa. Seluruh Tim mengikuti metode pembelajaran PiTBL dalam satu kelas besar.

Tabel 1. Karakteristik partisipan $(\mathrm{n}=103)$

Karakteristik Frekuensi

Jenis Kelamin

- Laki-laki

39 orang $(37.9 \%)$

- Perempuan

64 orang $(62.1 \%)$

Asal Kelas

- Kelas A

49 orang $(47.6 \%)$

- Kelas B 54 orang $(52.4 \%)$ 
Untuk sub-skala partisipasi kemungkinan hasil didapatkan adalah berkisar 5-25, dengan 15 sebagai nilai netral. Untuk sub-skala enjoyment kemungkinannya adalah berkisar $3-15$, dengan 9 sebagai nilai netral. Sementara untuk nilai total student engagement adalah berkisar $8-40$, dengan 24 sebagai nilai netral. Nilai di atas nilai netral menunjukkan nilai yang positif untuk PiTBL.

Sub-skala Partisipasi - Nilai signifikansi dari penurunan engagement dari PBL ke PiTBL untuk sub-skala partisipasi adalah sebagai berikut (berurutan dari minggu 1 ke 5): 1.000, 1.000, $.017,0.66$ dan 0.122 . Dengan nilai kepercayaan $95 \%(\mathrm{p}<0.05)$, maka nilai dari seluruh signifikansi adalah $\mathrm{p}>0.05$, hal ini berarti bahwa tidak ada perbedaan yang signifikan dari penurunan nilai yang dihasilkan. Demikian juga untuk signifikansi penurunan engagement pada PiTBL minggu-I ke II dan III (1.000, 1.000), minggu-II ke III (1.000), serta peningkatan dari minggu-III ke IV dan $\mathrm{V}$ (1.000, 1.000), minggu ke-IV ke V (1.000). Kesemuanya memiliki nilai signifikansi $>0.05$, yang berarti tidak ada perbedaan yang signifikan dari penurunan maupun peningkatan engagement untuk sub-skala partisipasi pada pembelajaran PiTBL di tiap minggunya.

Sub-skala Enjoyment - Nilai signifikansi dari penurunan engagement PBL ke PiTBL untuk subskala enjoyment secara berurutan tiap minggu (minggu-I sampai dengan ke-V) adalah sebagai berikut: $0.389,0.002,0.000,0.000,0.000$. Untuk signifikasi penurunan sub-skala enjoyment dari PBL ke PiTBL minggu-I nilai signifikasi 0.389 $>0.05$, artinya bahwa tidak ada perbedaan yang signifikan dari penurunan tersebut. Sementara signifikasi penurunan untuk minggu-II sampai dengan ke- $\mathrm{V}<0.05$, yang artinya bahwa terdapat perbedaan signifikan dari penurunan engagement untuk sub-skala enjoyment dari pembelajaran PBL ke pembelajaran PiTBL minggu-II sampai dengan minggu-V. Untuk signifikasi penurunan dari engagement pembelajaran PiTBL minggu-I ke II dan III $(1.000,0.50)$ dan minggu-II ke-III (1.000), serta signifikansi peningkatan dari minggu-III ke IV dan $V(1.000,1.000)$ dan minggu-IV ke minggu-V (1.000), semuanya memiliki nilai signifikasi $>0.05$, yang artinya bahwa tidak ada perbedaan signifikan dari penurunan dan peningkatan yang terjadi dalam pembelajaran PiTBL tiap minggunya.

Nilai Total Student Engagement - Nilai signifikansi dari penurunan nilai total engagement dari PBL ke PiTBL adalah sebagai berikut (berurutan dari minggu I ke V): $0.623,0.019,0.000,0.01$ dan 0.06. Dengan nilai kepercayaan $95 \%(\mathrm{p}<0.05)$, maka untuk penurunan dari engagement PBL ke PiTBL minggu-I, II dan $\mathrm{V}$ memiliki perbedaan nilai yang tidak signifikan, karena nilai $\mathrm{p}>0.05$. Sementara untuk penurunan dari engagement PBL ke PiTBL minggu ke-III dan IV, memiliki nilai signifikansi $<0.05$, sehingga dapat disimpulkan bahwa terdapat perbedaan yang signifikan terhadap nilai penurunannya. Untuk signifikansi penurunan engagement pada PiTBL minggu-I ke II dan III (1.000, 0.51), minggu-II ke III (1.000), serta peningkatan dari minggu-III ke IV dan V (1.000, 1.000), minggu-IV ke V (1.000), kesemuanya memiliki nilai signifikansi $>0.005$, yang berarti tidak ada perbedaan yang signifikan dari penurunan maupun peningkatan nilai total engagement dalam pembelajaran PiTBL tiap minggunya.

Hasil pengukuran baik pada nilai total maupun subskala partisipasi dan sub-skala enjoyment dari student engagement menunjukkan bahwa level engagement mahasiswa adalah positif, baik untuk pembelajaran PBL (pre-test) maupun pembelajaran PiTBL (post-test). Namun tidak terdapat peningkatan engagement mahasiswa dengan pembelajaran PiTBL dibandingkan dengan PBL. Dari minggu-1 sampai dengan minggu-5 pembelajaran PiTBL terjadi penurunan engagement dengan level penurunan yang tertinggi adalah pada minggu-3, baik untuk nilai total maupun untuk masing-masing sub-skala.

PiTBL merupakan integrasi dari kedua metode pembalajaran yang sesuai dengan prinsip pendekatan instruksional dari Merril. ${ }^{2}$ Prinsip tersebut adalah metode PBL dan TBL dapat membuat mahasiswa engaged dalam mendiskusikan kasus-kasus skenario yang sesuai dengan keadaan yang terjadi di dunia nyata. ${ }^{2}$ Selain itu student engagement merupakan konsep penting dan menjadi bagian integral dari metode pembelajaran TBL. ${ }^{6,10}$ Hasil penelitian tentang implementasi TBL dalam kurikulum PBL 
pada mahasiswa kedokteran tahun kedua merupakan strategi yang efektif untuk meningkatkan engagement, serta mengembangkan personal skill, produktivitas dalam diskusi, serta performa pada mahasiswa yang memiliki kemampuan akademik kurang. ${ }^{15}$ Selain itu mengurangi jumlah anggota kelompok menjadi 5-7 orang dan mendistribusikan kemampuan secara merata membuat kelompok lebih engaged selama proses diskusi. ${ }^{16}$

Jika dibandingkan dengan PBL, nilai student engagement pada PiTBL lebih rendah. Peneliti berpendapat bahwa penurunan ini dikarenakan oleh beberapa hal. Yang pertama adalah dikarenakan metode ini adalah metode baru, sehingga mahasiswa masih merasa asing dalam menjalaninya. Hal ini sesuai dengan hasil penelitian sebelumnya, bahwa selayaknya pengenalan sebuah metode pembelajaran dalam kurikulum baru, bahwa penerimaan dan kualitas dari pelaksanaan metode tersebut akan meningkat seiring dengan perkembangan waktu. ${ }^{17}$ Selain itu penelitian lain yang juga mengintegrasikan antara metode PBL dan TBL, menyatakan bahwa dampak dari perubahan cara belajar pada suatu metode baru adalah ketidaknyamanan dari mahasiswa, terutama jika mereka belum pernah mengalami sebelumnya bagaimana melakukan pembelajaran dengan metode tersebut. ${ }^{18}$

Hal penting lain yang menyebabkan adalah terkait dengan dinamika perkembangan kelompok, dimana pada PiTBL kelompok baru dibentuk untuk keperluan penelitian. Sebelum intervensi mahasiswa telah menjalani PBL selama 10 blok pembelajaran (6 blok pada tahun pertama dan 4 blok pada tahun kedua, selama hampir 2 tahun. Sementara dalam PiTBL mereka bekerja dalam Tim belajar yang baru dan hanya bertemu selama 5 kali proses diskusi PiTBL dalam 1 Blok. Dalam proses Team Building dibutuhkan fase-fase pembentukan yang dinamis, yang menurut Tuckman fase-fase tersebut meliputi forming, storming, norming dan performing. ${ }^{4}$ Sebuah kelompok akan berkembang menjadi Tim belajar yang high-performing setelah menjalani kerjasama selama beberapa waktu dan melalui beberapa kali pertemuan. Menurut aturan umum, proses ini membutuhkan sekitar 6-8 kali sesi belajar yang terpisah, dan berdasarkan perspektif ini disarankan supaya anggota-anggota kelompok harus bersama menjadi satu Tim selama minimal 15-20 pertemuan dalam diskusi. ${ }^{4}$

Teori dari Haidet et al dalam kerangka konsep menyebutkan ada beberapa hal yang mempengaruhi student engagement. Dan menurut asumsi peneiti, dari beberapa hal tersebut yang mempengaruhi dalam penelitian ini adalah penggunaan ruangan kelas besar untuk semua kelompok dan suasana belajar dalam kelas. ${ }^{14}$ Sementara papa metode PBL sebelumnya mereka terbiasa melakukan diskusi dalam kecil. Hal ini sesuai dengan hasil penelitian dari Burgess et al yang mendapatkan hasil bahwa dengan melakukan pembelajaran di kelas besar mahasiswa merasa bahwa sesi pembelajaran tersebut "felt a bit rushed". ${ }^{19}$ Selain itu pembelajaran PBL dalam kelas besar, selain berdampak positif secara ekonomis, namun membawa beberapa resiko. Diantaranya adalah kurang terpenuhinya harapan dari beberapa mahasiswa untuk dapat mendapatkan banyak pengetahuan dari proses pembelajaran dalam kelas besar, selain itu juga proses diskusi dalam kelas besar dirasa impersonal dan beberapa mahasiswa merasa asing karena terbiasa dengan proses pembelajaran sebelumnya di kelas-kelas kecil. ${ }^{19}$

Selain itu hal di dalam kerangka konsep tentang engagement dari Haidet et al juga menyebutkan bahwa course factor juga dapat mempengaruhi nilai engagement. ${ }^{14}$ Di dalam Blok pembelajaran PiTBL pada penelitian ini, distribusi dari konten (asuhan keperawatan untuk kasus penyakit) tidak merata. Konten asuhan keperawatan untuk kasus penyakit mulai banyak diberikan di Minggu-III dan seterusnya. Hal ini menyebabkan engagement pada minggu tersebut menjadi paling rendah.

\section{Persepsi Mahasiswa}

Terdapat tiga sub-skala dalam persepsi mahasiswa tentang pengalaman belajar mereka dengan PiTBL selain persepsi secara total, yaitu: akuntabilitas, preferensi dan kepuasan.

Pada sub-skala Akuntabilitas kemungkinan nilai yang didapatkan adalah antara $8-40$, dengan nilai 
24 sebagai nilai netral. Hasil yang didapatkan pada penelitian ini untuk sub-skala Akuntabilitas adalah berkisar antara 24-40, dengan nilai mean 31.55 $(\mathrm{SD}=2.79$; lihat gambar 3$)$.
Hasil positif yang didapatkan untuk sub-skala ini menurut asumsi peneliti adalah metode PiTBL menggunakan kerangka dan desain utama dari pembelajaran TBL. Akuntabilitas merupakan bagian dari TBL, dimana individu memiliki akuntabilitas untuk belajar mandiri, yang

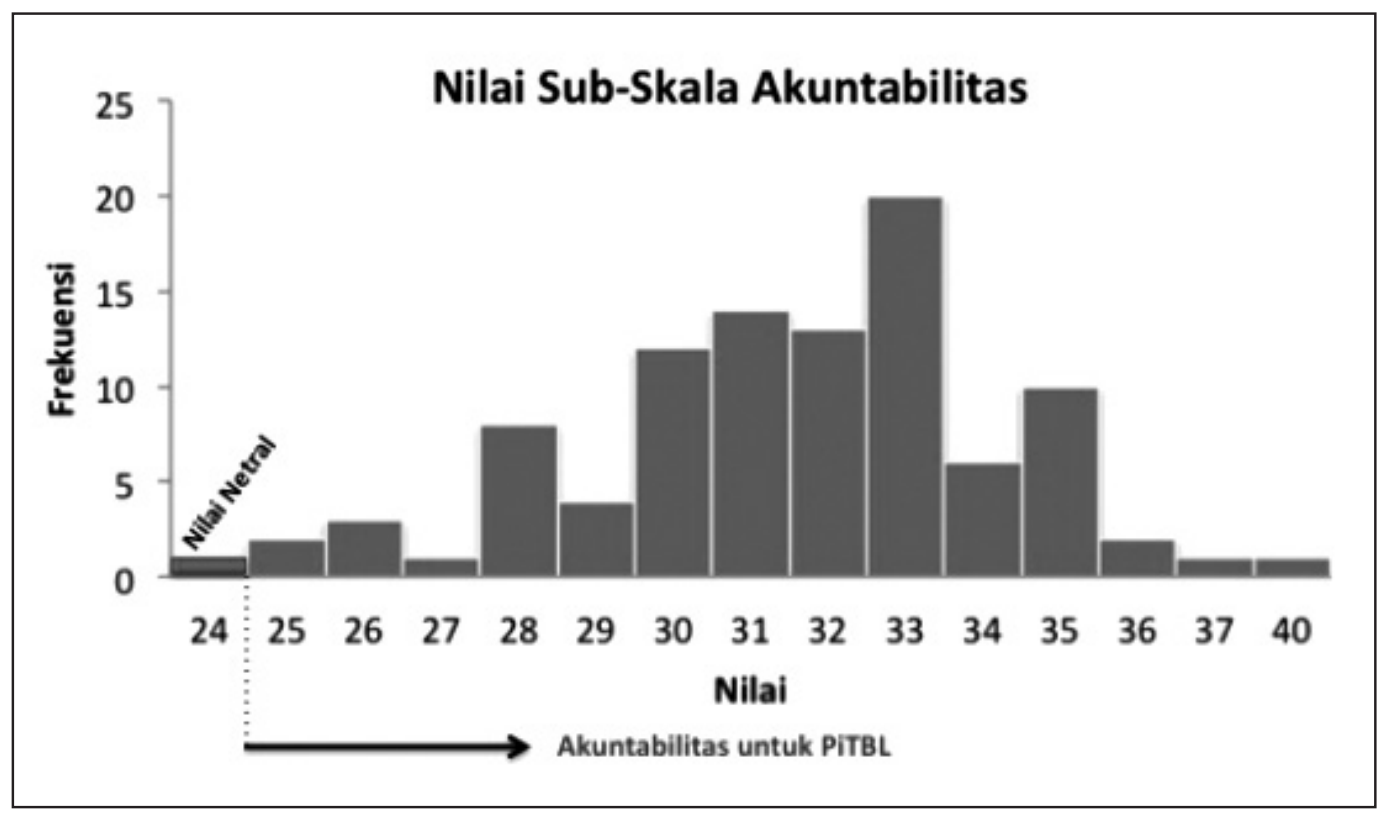

Gambar 3. Distribusi Frekuensi Nilai Sub-Skala Akuntabilitas PiTBL-SAI ( $\mathrm{n}=98)$

berdampak pada interaksi Tim yang kuat dalam meningkatkan kompetensi dan kapabilitas undividu dalam belajar. ${ }^{17,21}$ Di dalam TBL akuntabilitas ini muncul dengan penilaian (grading) dan evaluasi performa mereka di kelas. TBL menciptakan sebuah kebutuhan untuk mahasiswa bahwa mereka harus belajar dan memberikan insentif pada mahasiswa tentang performa mereka dalam menyampaikan hasil belajarnya. Sehingga hal ini membuat mahasiswa bertangung-jawab atau akuntabel terhadap proses pembelajaran yang mereka jalani. ${ }^{4}$

Ada beberapa bentuk akuntabilitas dari mahasiswa dalam TBL, yaitu: akuntabilitas dalam melakukan belajar mandiri di luar kelas (Pre-class Preparation) yang dipengaruhi oleh penilaian terhadap iRAT (Tes Kesiapan Individu); akuntabilitas dalam berkontribusi pada diskusi kelompok, atau persiapan kolektif Tim yang dipengaruhi oleh penilaian terhadap tRAT (Tes Kesiapan Tim); akuntabilitas dalam melakukan kerja Tim yang berkualitas dalam hal aplikasi dari pengetahuan dasar yang telah dipelajari dalam menyelesaikan skenario kasus yang kompleks, yang dipengaruhi oleh penilaian terhadap Soal-Soal Skenario dalam tahap Application; dan akuntabilitas dalam berkontribusi pada dinamika kelompok, menjaga kekompakan dan produktivitas Tim yang dinilai dari Peer Evaluation. ${ }^{21,22}$

Pada sub-skala Preferensi kemungkinan nilai adalah berkisar antara $16-80$, dengan nilai 48 sebagai nilai netral. Hasil yang didapatkan untuk sub-skala Preferensi pada penelitian ini adalah 39 - 64, dengan nilai mean $50.5(\mathrm{SD}=4.44$, lihat gambar 4).

Meskipun hasil dari pengukuran terhadap student engagement PiTBL lebih rendah daripada PBL, serta metode PiTBL ini merupakan hal yang baru dan menambah beban mahasiswa untuk lebih mempersiapkan diri dalam proses pembelajaran, preferensi mereka lebih positif untuk PiTBL. 


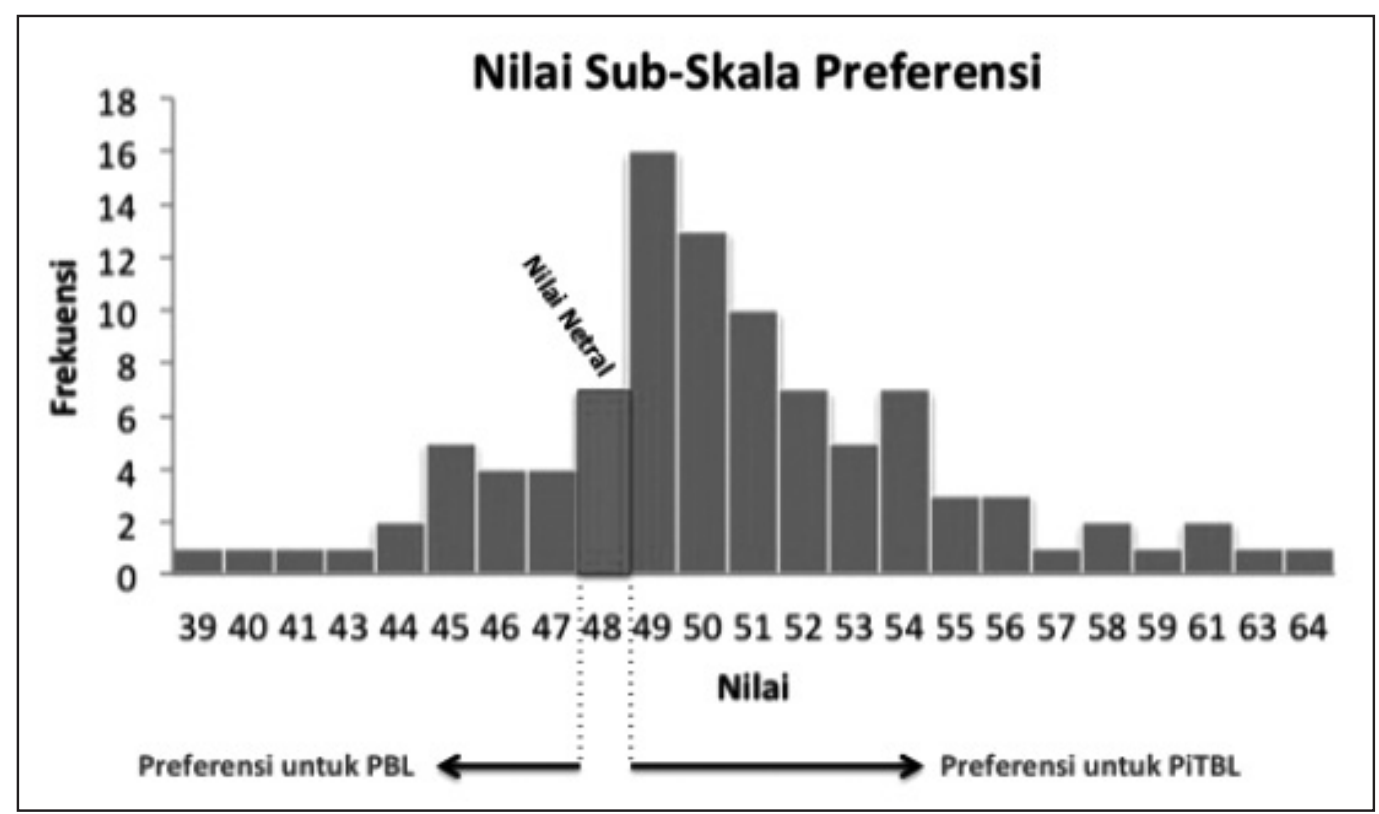

Gambar 4. Distribusi Frekuensi Nilai Sub-Skala Preferensi PiTBL-SAI ( $\mathrm{n}=98)$

Jika dikaji dari hasil pertanyaan open-ended pada instrumen PiTBL-SAI, sejumlah 43 partisipan (43,9\%, n=98) menyatakan bahwa metode PiTBL ini menyenangkan. Sehinggadengan adanyapersepsi tersebut mahasiswa cenderung untuk menyukai dan lebih memiliki preferensi yang baik terhadap metode ini. Konsisten dengan hasil penelitian Haidet et al yang menyatakan bahwa proses diskusi dalam TBL, dimana mahasiswa melakukan diskusi dalam kelompok kecil untuk menyepakati suatu jawaban, kemudian membandingkan jawaban dengan Tim yang lain untuk soal yang sama, proses diskusi antar Tim untuk saling berargumentasi dalam mempertahankan jawaban masing-masing adalah menjadi hal yang menyenangkan menurut mahasiswa, dan dapat lebih mendorong antusiasme mereka dalam belajar.

Sejumlah 17 partisipan (17.35\%, n=98) menyatakan bahwa mereka lebih mempersiapkan diri untuk proses belajar dalam kelas, sejumlah 16 partisipan $(16.35 \%, \mathrm{n}=98)$ menyatakan bahwa mereka lebih memahami materi dan 12 partisipan $(12.24 \%, \mathrm{n}=98)$ menyatakan bahwa mereka lebih siap dalam menghadapi ujian dengan metode PiTBL. Dari beberapa pendapat ini peneliti menyimpulkan bahwa ekspektasi mahasiswa terhadap suatu proses pembelajaran terpenuhi dengan metode PiTBL, sehingga preferensi mereka pada metode ini lebih tinggi. Hal ini sesuai dengan pernyataan dari Osfad \& Brunner dalam Hrynchak $\&$ Spafford $^{23}$ yang menyatakan bahwa banyak dari mahasiswa pendidikan profesi kesehatan yang menginginkan penerapan dari TBL dalam program pembelajarannya karena mereka merasa dengan metode ini mereka mendapatkan manfaat yang dapat meningkatkan pencapaian belajar mereka di lingkungan belajar yang kompetitif.

Pada sub-skala Kepuasan mahasiswa, kemungkinan nilai yang didapatkan adalah antara 9-45, dengan nilai 27 sebagai nilai netral. Hasil yang didapatkan untuk sub-skala Kepuasan pada penelitian ini adalah berkisar antara 22-43, dengan nilai mean $33.39(\mathrm{SD}=4.59$; lihat gambar 5$)$.

Meskipun PiTBL merupakan hal baru bagi mahasiswa, namun setelah beberapa kali menjalani hal ini menjadi familiar dan mahasiswa terbiasa dengan metode ini. Hal ini sesuai dengan hasil penelitian yang menyebutkan bahwa mahasiswa 


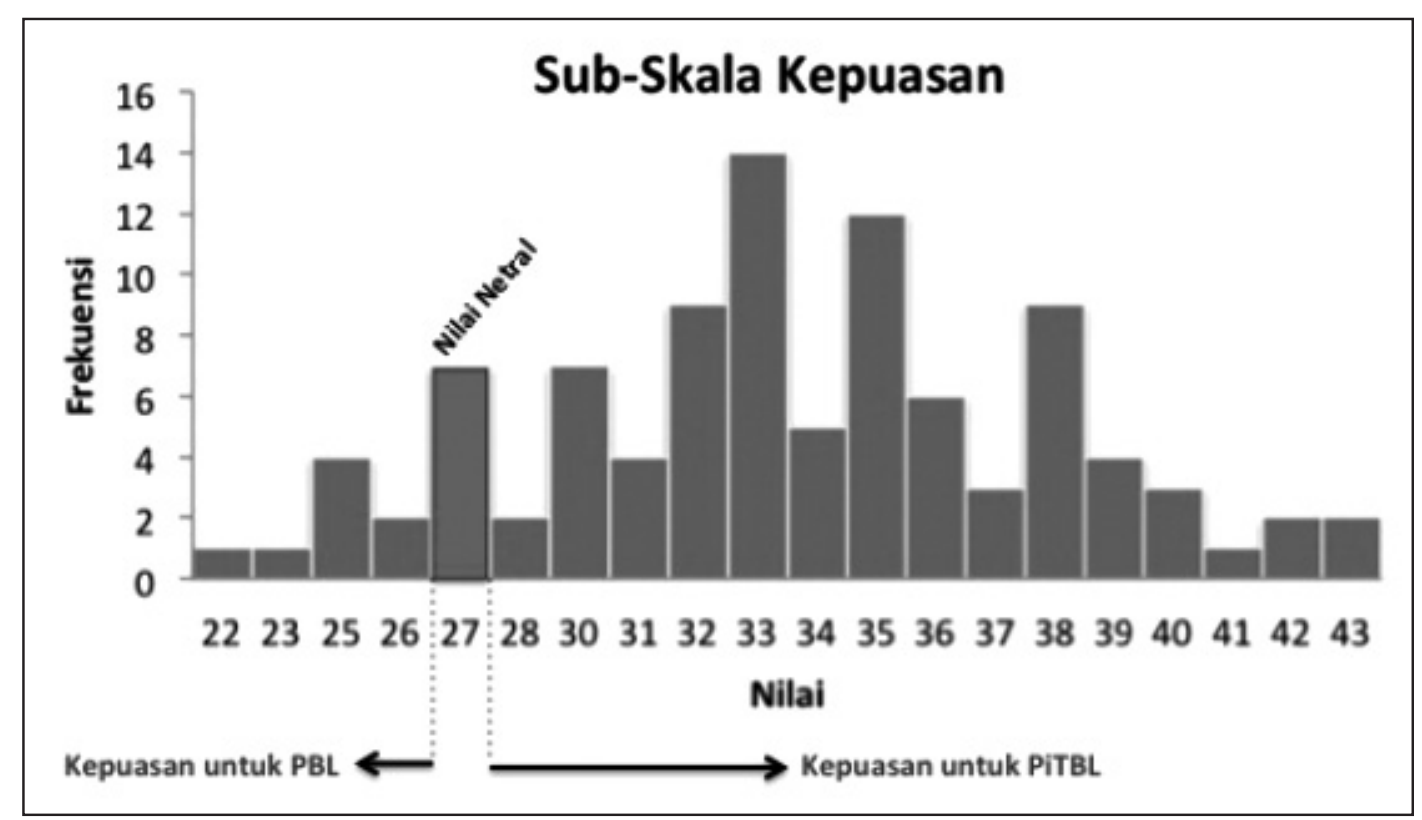

Gambar 5. Distribusi Frekuensi Nilai Sub-Skala Kepuasan PiTBL-SAI ( $=98)$

mengalami tingkat kepuasan yang meningkat dengan metode pembelajaran ini dikarenakan kontribusi yang menyeluruh dari semua anggota Tim dan kerjasama Tim yang maksimal pada proses pembelajaran $\mathrm{TBL}^{24}$ Seperti yang telah disebutkan di atas, bahwa partisipan merasa bahwa mereka mendapatkan manfaat dalam pembelajaran dengan metode PiTBL. Mereka merasa bahwa kemampuan dalam mengingat dan memahami materi pembelajaran menjadi lebih baik dan mereka merasa lebih siap dalam menghadapi ujian. Hal ini menyebabkan tingkat kepuasan mereka terhadap metode ini tinggi karena tujuan dari proses pembelajaran yang mereka harapkan dapat tercapai dengan lebih baik. Salain itu partisipan juga menyatakan bahwa metode ini menyenangkan. Smith ${ }^{25}$ menyebutkan bahwa mahasiswa memiliki tingkat kepuasan yang baik terhadap suatu metode pembelajaran jika mereka mengalami pengalaman belajar yang menyenangkan dengan metode tersebut dan dapat meningkatkan kemampuan mereka dalam memahami konten pembelajaran yang diajarkan.

Dan untuk nilai total instrumen dihitung dengan kemungkinan hasil penilaian berkisar antara 33 165, dengan nilai 99 sebagai nilai netral. Hasil yang diperoleh untuk nilai total adalah berkisar 90 139, dengan mean sebesar $115.44(\mathrm{SD}=9.15$, lihat gambar 6).

Dari hasil koding data kualitatif instrumen PiTBLSAI didapatkan tiga kategori utama: persepsi positif, persepsi negatif dan dampak terhadap pembelajaran, dan terdapat beberapa sub-kategori. 


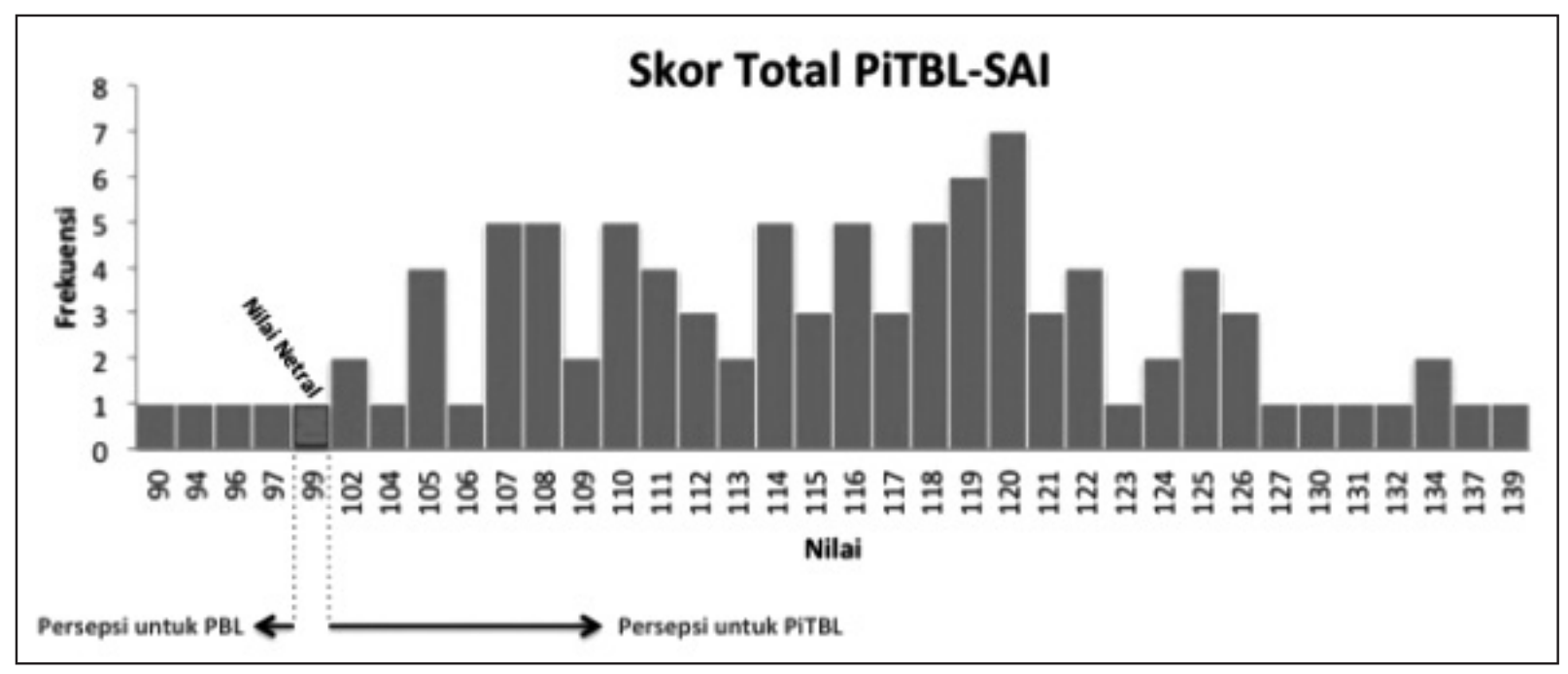

Gambar 6. Distribusi Frekuensi Nilai Total PiTBL-SAI $(\mathrm{n}=98)$

Tabel 2. Data Kualitatif instrumen PiTBL-SAI $(\mathrm{n}=98)$

\begin{tabular}{|c|c|c|}
\hline Kategori & Sub-Kategori & Jumlah \\
\hline \multirow{3}{*}{$\begin{array}{l}\text { Persepsi } \\
\text { Positif }\end{array}$} & Menyenangkan & 43 \\
\hline & Tidak membosankan & 17 \\
\hline & Efektif & 10 \\
\hline \multirow{3}{*}{$\begin{array}{l}\text { Persepsi } \\
\text { Negatif }\end{array}$} & $\begin{array}{l}\text { Alokasi waktu terlalu } \\
\text { panjang }\end{array}$ & 32 \\
\hline & $\begin{array}{l}\text { Susah fokus karena terlalu } \\
\text { berisik }\end{array}$ & 24 \\
\hline & $\begin{array}{l}\text { Kurang suka pertemuan } \\
\text { pertama }\end{array}$ & 14 \\
\hline \multirow{3}{*}{$\begin{array}{l}\text { Dampak } \\
\text { terhadap } \\
\text { pembelajaran }\end{array}$} & $\begin{array}{l}\text { Lebih mempersiapkan } \\
\text { diri sebelum mengikuti } \\
\text { pembelajaran dalam kelas }\end{array}$ & 17 \\
\hline & $\begin{array}{l}\text { Mudah mengingat dan } \\
\text { memahami materi }\end{array}$ & 16 \\
\hline & $\begin{array}{l}\text { Meningkatkan kesiapan } \\
\text { menghadapi ujian }\end{array}$ & 12 \\
\hline
\end{tabular}

Penelitian ini memiliki beberapa keterbatasan yang peneliti dapatkan selama proses di lapangan dan telah berusaha untuk meminimalisir keterbatasan-keterbatasan tersebut. Pertama, tidak adanya kelompok kontrol sebagai pembanding. Dikarenakan penelitian ini masih berupa uji coba dan adanya regulasi dari institusi terkait masalah etik, sehingga peneliti tidak menggunakan kelompok kontrol. Pembanding untuk nilai student engagement pada metode pembelajaran PBL didapatkan dengan nilai pre test, yang dilakukan pada akhir Blok Pembelajaran sebelumnya yang menggunakan metode pembelajaran sebelum intervensi. Kedua, durasi waktu pelaksanaan intervensi hanya lima minggu, yang menurut asumsi peneliti kurang bisa mendapatkan hasil yang maksimal untuk student engagement. Hal ini disebabkan karena dinamika perkembangan kelompok yang membutuhkan waktus setidaknya 15-20 kali pertemuan untuk dapat menjadi highperforming team. ${ }^{4}$ Ketiga, peneliti tidak melakukan uji validitas dan reliabilitas ulang untuk instrumen penelitian, meskipun insturmen penelitian telah digunakan di beberapa penelitian sebelumnya dan menunjukkan nilai validitas dan reliabilitas yang tinggi. Keempat, dosen belum memiliki pengalaman dalam memfasilitasi diskusi PBL dalam kelas besar. Sehingga peneliti memberikan mini workshop dengan mengundang pakar untuk merefresh tentang bagaimana peran fasilitator dalam PBL. Selain itu peneliti melakukan On The Job Training, yaitu melakukan supervisi, evaluasi dan kemudian memberikan feedback di tiap akhir intervensi.

\section{KESIMPULAN}

Metode pembelajaran PiTBL mampu membuat student engagement postitif. Hal ini dibuktikan 
dengan nilai rata-rata student engagement di tiap sub-skala maupun nilai total di atas nilai netral tiap minggunya. Tetapi jika dibandingkan dengan student engagement pada metode pembelajaran PBL yang dijalani mahasiswa sebelumnya, nilainya lebih rendah. Pada sub-skala partisipasi tidak menunjukkan perbedaan yang signifikan, untuk sub-skala enjoyment perbedaan antara PBL dengan PiTBL minggu-II sampai $\mathrm{V}$ menunjukkan perbedaan yang signifikan, dan untuk nilai total perbedaan signifikan pada minggu-III dan IV. Untuk semua sub-skala dan nilai total perbedaan nilai paling signifikan adalah pada minggu-III. Penurunan nilai student engagement kemungkinan disebabkan oleh karena dinamika perkembangan Tim yang baru terbentuk belum maksimal, distribusi konten pembelajaran yang tidak merata di tiap minggu yang menyebabkan penurunan tertinggi ada pada minggu-III, dan dikarenakan metode ini merupakan metode baru untuk mahasiswa. Persepsi mahasiswa dalam hal akuntabilitas, preferensi dan kepuasan mereka terhadap metode pembelajaran PiTBL semuanya menunjukkan hasil yang positif. Dari beberapa hasil tersebut peneliti berasumsi bahwa metode pembelajaran PiTBL dapat digunakan sebagai alternatif bagi institusi yang membutuhkan metode pembelajaran active learning yang tidak membutuhkan banyak sumber daya dalam implementasinya.

\section{UCAPAN TERIMAKASIH}

Peneliti mengucapkan terimakasih kepada Gandes Retno Rahayu, dr., MMedEd, PhD dan Savitri Shitarukmi, dr., MHPE., yang banyak memberikan saran dan telaah pada penelitian ini. Peneliti juga mengucapkan terima kasih kepada Ketua STIKES Banyuwangi Dr. H. Soekardjo, S.Kep., MM., dan seluruh civitas akademikanya, jajaran struktural dan civitas akademika STIKES Achmad Yani Yogyakarta, Tim Blok PiTBL: Retno Sumiyarini, S.Kep. Ns., MMedEd., Dewi Retno Pamungkas, MNg., Dewi Utari, MNg., Anastasia Suci Sukmawati, MNg., Ika Parmawati, M.Kep., serta mahasiswa Prodi S1 Keperawatan STIKES Achmad Yani angkatan 2014 yang telah berpartisipasi aktif dan membantu proses penelitian ini.

\section{DAFTAR PUSTAKA}

1. Haidet P, O'Malley KJ, Richards B. An initial experience with "Team-learning" in Medical Education. Academic Medicine. 2005; 77:40-4.

2. Dolmans D, Michaelsen L, Merrienboer JV, Vleuten CVD. Should we choose between problem-based learning and team-based learning? No, combine the best of both worlds! Medical Teacher. 2015;37:354-9.

3. Frenk J, Chen LC, Bhutta ZA. Health professionals for a new century: transforming education to strengthen health systems in an interdependent world. The Lancet. 2010;376:1923-57.

4. McMahon KK. Team-Based Learning. Jeffries WB \& Hugget KN (ed.): An Introduction to Medical Teaching, pp:55-64. Springer, New York; 2010.

5. Thompson BM, Schneider VF, Haidet P, Levine RE, McMahon KK, Perkowski LC, Richards BF. Team-based learning at ten medical schools: two years later. Medical Education. 2007;41:250-7.

6. Parmelee DX. Team-based learning: Moving forward in curriculum innovation: A commentary. Medical Teacher. 2010;32:105-7.

7. Kelly PA, Haidet P, Schneider V, Searle N, Seidel CL, Richards BF. A comparison of InClass Learner Engagement Across Lecture, Problem-Based Learning, and Team Learning Using the Strobe Classroom Observation Tool. Teaching and Learning in Medicine. 2005;17(2).

8. Parmelee DX, Michaelsen LK, Cook S, Hudes PD. Team-based learning: A practical guide: AMEE Guide No:65. Medical Teacher. 2012;34:e275-87.

9. Fund for the Improvement of Postsecondary Education. Baylor University: Evaluation of team learning in health-sciences education. 2003. Retrieved from: http:// www.fipse.aed.org/grantshow.cfm?grant Number $=$ P116B000884\& printGrant $=$ yes

10. Mennenga HA. Team-based learning: Engagement and accountability with psychometric analysis of a new instrument. UNLV Theses/Dessertations/Professional Papers/Capstones. Paper 854; 2010. 
11. Kingsbury MP, Lymn JS. Problem-based learning and larger student groups: mutually exclusive or compatible concepts - pilot study. BMC Medical Education. 2008;8(35).

12. Pastirik PJ. Using problem-based learning in a large classroom. Nurse Education in Practice. 2006;6: 261-7.

13. Nicholl TA, Lou K. A Model for Small-Group Problem-Based Learning in a Large Class Facilitated by One Instructor. American Journal of Pharmaceutical Education. 2011;76(6).

14. Haidet P, Levine RE, Parmelee DX, Crow S, Kennedy F, Kelly PA, Perkowski L, Michaelsen L, Richards BF. Perspetive: Guidelines for Reporting Team-Based Learning Activities in the Medical and Health Sciences Education Literature. Academic Medicine. 2012;87(3).

15. Vogeltanz-Holm N, Olson LM, Borg KE, Hill TM. Implementation and Evaluation of a TeamBased Learning Approach Within a Hybrid Problem-Based Learning Medical Education Curriculum. Med Sci Educ. 2014;24(125).

16. Michaelsen L, Richards B. Commentary: Drawing Conclusions from the Team-Learning Literature in Health-Sciences Education: A Commentary. Teaching and Learning in Medicine. 2005;17(1):85-8.

17. Vasan NS, DeFouw DO, Holland BK. Modified Use of Team-Based Learning for Effective Delivery of Medical Gross Anatomy and Embryology. Anat Sci Educ. 2007;1:3-9.

18. Chuangchum P, Pholchan T, Napkesorn T, Pannarunothai S. Effects of using an integrated team-based and problem-based learning approach for developing lifelong learning karakteristik of first year medical students. South-East Asian Journal of Medical Education. 2011;5(2).
19. Burgess A, Ayton T, Mellis C. Implementation of team-based learning in year 1 of a PBL based medical program: a pilot study. BMC Medical Education. 2016;16(49).

20. Oliver R (Ed). Using a blended learning approach to support problem-based learning with first year students in large undergraduate classes. Proceeding of the 2005 conference on Towards Sustainable and Scalable Educational Innovations Informed by the Learning Sciences: Sharing Good Practices of Research, Experimental and Innovations. 2005;pp.84851.

21. Michaelsen LK, Sweet M. The Essential Elements of Team-Based Learning. New Directions for Teaching and Learning. 2008:116. Published online in Wiley Interscience (www.interscience.wiley.com).

22. Cestone CM, Levine RE, Lane DR. Peer Assessment and Evaluation in Team-Based Learning. New Directions for Teaching and Learning. 2008;116. Published online in Wiley Interscience (www.interscience.wiley.com).

23. Hrynchak PK, Spafford MM. Optometry Students' Attitudes about Team-Based Learning. Optometric Education. 2015;40(2):8993.

24. Parmelee DX, DeStephen D, Borges NJ. Medical students' attitudes about Team-based learning in a pre-clinical curriculum. Med Educ Online. 2009;14(1).

25. Koles PG, Stolfi A, Borges NJ, Nelson $S$, Parmelee DX. The Impact of TeamBased learning on Medical Students' Academic Performance. Academic Medicine. 2010;85(11):1739-45. 